\title{
Influence of cell cycle on responses of MCF-7 cells to benzo[a]pyrene
}

\author{
Hamza Hamouchene*, Volker M Arlt, lan Giddings and David H Phillips
}

\begin{abstract}
Background: Benzo[a]pyrene (BaP) is a widespread environmental genotoxic carcinogen that damages DNA by forming adducts. This damage along with activation of the aryl hydrocarbon receptor (AHR) induces complex transcriptional responses in cells. To investigate whether human cells are more susceptible to BaP in a particular phase of the cell cycle, synchronised breast carcinoma MCF-7 cells were exposed to BaP. Cell cycle progression was analysed by flow cytometry, DNA adduct formation was assessed by ${ }^{32} \mathrm{P}$-postlabeling analysis, microarrays of 44K human genome-wide oligos and RT-PCR were used to detect gene expression (mRNA) changes and Western blotting was performed to determine the expression of some proteins, including cytochrome P450 (CYP) 1A1 and CYP1B1, which are involved in BaP metabolism.

Results: Following BaP exposure, cells evaded G1 arrest and accumulated in S-phase. Higher levels of DNA damage occurred in S- and G2/M- compared with GO/G1-enriched cultures. Genes that were found to have altered expression included those involved in xenobiotic metabolism, apoptosis, cell cycle regulation and DNA repair. Gene ontology and pathway analysis showed the involvement of various signalling pathways in response to BaP exposure, such as the Catenin/Wnt pathway in G1, the ERK pathway in G1 and S, the Nrf2 pathway in S and G2/M and the Akt pathway in G2/M. An important finding was that higher levels of DNA damage in S- and G2/Menriched cultures correlated with higher levels of CYP1A1 and CYP1B1 mRNA and proteins. Moreover, exposure of synchronised MCF-7 cells to BaP-7,8-diol-9,10-epoxide (BPDE), the ultimate carcinogenic metabolite of BaP, did not result in significant changes in DNA adduct levels at different phases of the cell cycle.

Conclusions: This study characterised the complex gene response to BaP in MCF-7 cells and revealed a strong correlation between the varying efficiency of BaP metabolism and DNA damage in different phases of the cell cycle. Our results suggest that growth kinetics within a target-cell population may be important determinants of susceptibility and response to a genotoxic agent.
\end{abstract}

\section{Background}

Chemical carcinogens that act by a genotoxic mechanism exert their biological effects through damaging DNA. This damage can be manifested in several forms, including single or double strand breaks, apurinic sites and covalent modification of the bases. Some chemical carcinogens such as benzo[a]pyrene (BaP), which is a representative of the class of polycyclic aromatic hydrocarbons (PAHs), are thought to cause cancer through covalent binding of their reactive metabolites to DNA, forming DNA adducts [1-3]. BaP-7,8-diol-9,10-epoxides (BPDE), the ultimate carcinogenic metabolites of BaP,

\footnotetext{
* Correspondence: hamza.hamouchene@icr.ac.uk

Section of Molecular Carcinogenesis, Institute of Cancer Research, Brookes Lawley Building, Cotswold Road, Sutton, Surrey SM2 5NG, UK
}

react predominantly with the $\mathrm{N}^{2}$ position of guanine residues and to a lesser extent with the $\mathrm{N}^{6}$ position of adenine residues in DNA [4].

In mammalian cells $\mathrm{BaP}$ binds to the aryl hydrocarbon receptor (AHR), which is a cytosolic ligand-activated transcription factor that functions as a sensor of extracellular signals and environmental stresses affecting cell growth and development. AHR controls the expression of genes coding for xenobiotic-metabolising enzymes such as cytochrome P450s (CYPs), UDP-glucuronosyltransferase UGT1A6, NAD(P)H:quinone oxidoreductase-1 (NQO1), aldehyde dehydrogenase (ALDH3A1), and several glutathione-S-transferases [5]. It is also involved in regulation of development and in the control

\section{() Biomed Central}


of circadian rhythms, neurogenesis and stress response to hypoxia [6].

More recently it has also become evident that AHR has another function, namely in controlling cell cycle progression. For instance, high-affinity AHR ligands, such as some PAHs, cause a wide range of cell-cycle perturbations, including G0/G1 arrest or its evasion (the stealth property) [7], G2/M arrest, $S$-phase accumulation, diminished capacity for DNA replication and inhibition of cell proliferation [8]. These perturbations have been documented in several gene expression profiling studies. Previously we have used microarray technology to analyse the transcriptomes of several human cell lines exposed to $\mathrm{BaP}[9,10]$. Altered expression of a number of genes involved in cell cycle regulation were identified, including $C D K N 1 A, M A K, B T G 2$, CCNG1 and E2F6. Other studies have shown that upregulated AHR-dependent activation of CYP1A1 following $\mathrm{BaP}$ exposure may be dependent on the cellcycle phase [11-13], suggesting that the phase of the cell cycle may be critical to some of the effects of $\mathrm{BaP}$ on human cells.

In this study, we investigated whether cells are more susceptible to a genotoxic carcinogen, namely BaP, at particular phases of the cell cycle and, if so, to elucidate the processes involved. DNA microarrays were used to examine changes in gene expression throughout the cell cycle in synchronised human breast carcinoma MCF-7 cells following exposure to non-cytotoxic concentrations of BaP. Cell cycle phase-specific changes in gene expression profiles resulting from carcinogen exposure have identified novel genes and pathways potentially involved in the carcinogenic process. To strengthen the process of identifying target genes, gene expression data were compared to other biological parameters, including DNA adduct formation, determined by ${ }^{32} \mathrm{P}$-postlabelling analysis, and cell cycle progression, measured by FACS analysis.

\section{Results}

\section{Cell cycle progression}

In initial experiments, the optimum time of treatment with $\mathrm{BaP}$ was determined to be $12 \mathrm{~h}$. This gave sufficient time for cells to metabolise BaP to DNA-binding reactive intermediates, but minimised the extent to which untreated synchronised cells altered their cellcycle phase composition. In the case of G0/G1 enrichment, cells will start exiting the quiescent state $(G 0)$ and entering G1 soon after adding the serum back to the medium. Thus, from now on, these cells are referred to as G1-enriched. In previous work, the treatment concentration of $2.5 \mu \mathrm{M}$ was found to induce DNA adduct formation in MCF-7 cells within a linear dose-response range [9].
G1-enriched cultures (serum deprivation for $48 \mathrm{~h}$ ) did not differ significantly in the proportions of cells in different phases after treatment for $12 \mathrm{~h}$ with $\mathrm{BaP}$ compared with DMSO-treated controls (Figure 1A and Additional file $1 \mathrm{~A}$ ). Cells were progressing through the cell cycle and started entering $S$ and $G 2 / M$ phases by the end of the treatment. We did not observe a $G 1$ arrest after BaP treatment.

Exposure of $S$-enriched cultures (18 h after $48 \mathrm{~h}$ of serum deprivation) to $\mathrm{BaP}$ evoked dramatic alterations in cell cycle distribution with an increase of the fraction of cells in $S$-phase (59.6 vs 32.4, $P<0.001$; Figure 1B and Additional file 1B). The percentage of cells in G2/ $M$-phase was significantly lower than in control cultures $(P<0.001)$.

Similarly, BaP treatment of $G 2 / M$-enriched cultures (24 h treatment with $1 \mu \mathrm{g} / \mathrm{mL}$ aphidicolin followed by $12 \mathrm{~h} 0.25 \mu \mathrm{M}$ colchicine) increased the proportion of cells in $S$-phase (17.6 vs 11.2, $P=0.0045$; Figure $1 \mathrm{C}$ and Additional file 1C).

\section{DNA damage in synchronised MCF-7 cells}

BaP-DNA adduct formation was determined by the ${ }^{32} \mathrm{P}$ postlabelling method. Cells enriched in G1, $S$ and $G 2 / M$ that were exposed to $\mathrm{BaP}$ for $12 \mathrm{~h}$ showed different levels of DNA adducts (Figure 2A). Levels of adducts in the $S$ - and $G 2 / M$-enriched cultures were 3 to 4 -fold higher than levels observed in G1-enriched cultures.

When cells were treated with BPDE for $12 \mathrm{~h}$, the reactive metabolite of $\mathrm{BaP}$, similar levels of DNA adducts were formed in all cultures regardless of cell-cycle phase (Figure 2B). Since BPDE does not require metabolic activation to bind to DNA, and has a short half-life in aqueous environments, this result suggests that the differences observed with $\mathrm{BaP}$ are the consequence of different capacities to metabolically activate $\mathrm{BaP}$ at different stages of the cell cycle.

\section{BaP-induced gene expression changes by microarray analysis}

cDNA microarray analysis was carried out on synchronised cultures of MCF-7 cells enriched in G1, S and G2/ $M$ phases and exposed to $2.5 \mu \mathrm{M} \mathrm{BaP}$ for $12 \mathrm{~h}$.

Condition clustering and principal component analysis (PCA) revealed that exposure to $\mathrm{BaP}$ resulted in expression profiles more distinguishable by cell-cycle phase than by treatment (Figure 3).

Differentially expressed genes in each enriched culture were identified using Student's $t$-test and a cut-off of 1.5 -fold change in expression. This resulted in 417 genes in G1-, 189 genes in S-, and 519 genes in G2/Menriched cultures (Figure 4). 16 genes were shared between all phases (Additional file 2), 11 between $G 1$ and $S$ only (Additional file 3), 37 between $G 1$ and G2/M 
A

$12 \mathrm{~h}$ BaP treatment of G1-enriched cells

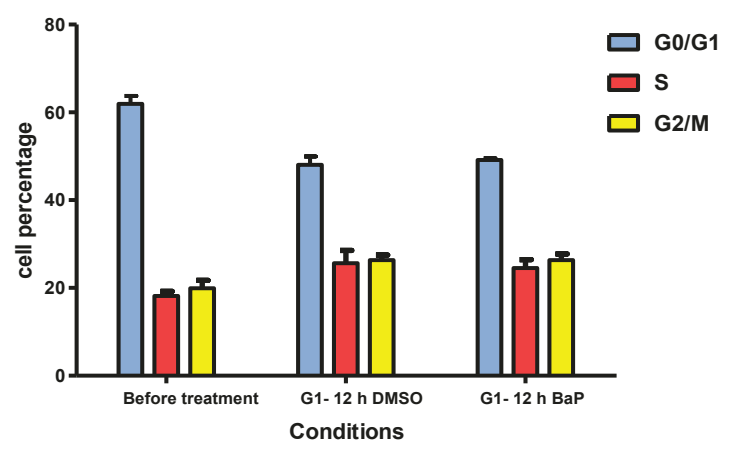

B

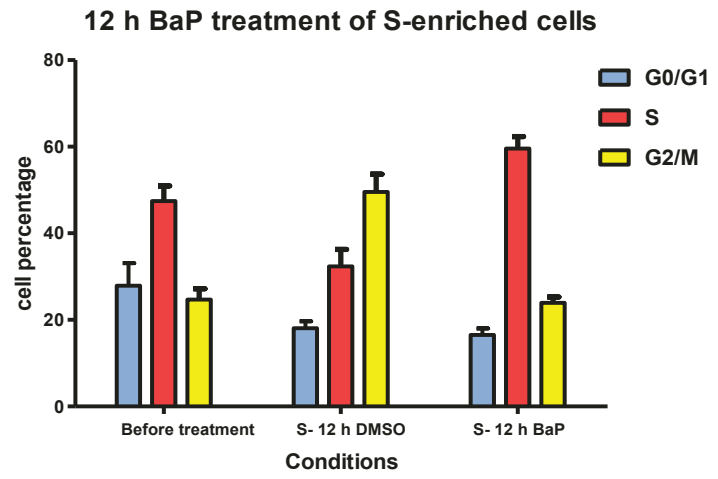

C

$12 \mathrm{~h}$ BaP treatment of G2/M-enriched cells

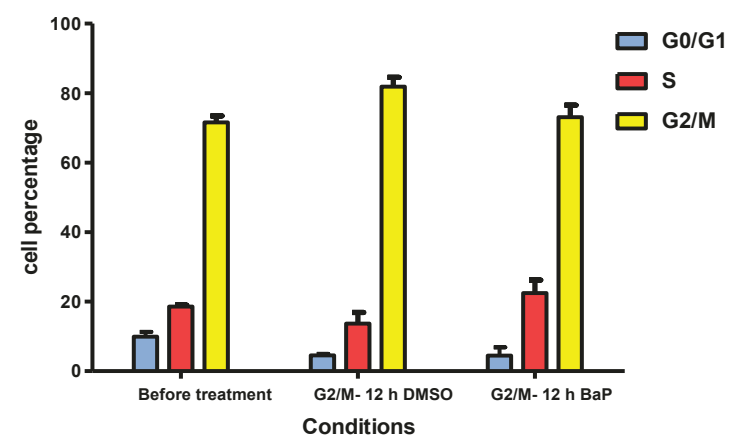

Figure 1 BaP delays escape from S-phase. A- MCF-7 cells were synchronised in G0/G1-phase by serum-deprivation for 48 hours, after which cells were exposed for $12 \mathrm{~h}$ to $\mathrm{BaP}(2.5 \mu \mathrm{M})$ or DMSO. B- MCF-7 cells were enriched in S-phase by serum-deprivation for $48 \mathrm{~h}$, then left to grow for $18 \mathrm{~h}$, after which they were treated by either BaP $(2.5 \mu \mathrm{M})$ or DMSO for $12 \mathrm{~h}$. C- MCF-7 cells were synchronised in G2/M-phase by exposing them to aphidicolin $(1 \mu \mathrm{g} /$ $\mathrm{mL})$ for $24 \mathrm{~h}$ followed by colchicine $(0.25 \mu \mathrm{M})$ for $12 \mathrm{~h}$.

Subsequently, they were released into media containing either BaP $(2.5 \mu \mathrm{M})$ or DMSO for $12 \mathrm{~h}$. Cell cycle distribution was examined by flow cytometry. The profiles are representative of three independent experiments. only (Additional file 4), and 32 between $S$ and $G 2 / M$ only (Additional file 5). However, the majority of modulated genes were cell-cycle specific (Figure 4).

Functional annotations of BaP-modulated genes

In order to find biological processes significantly overrepresented in the gene lists generated by statistical analysis, overlay of gene ontology information was carried out using the Gene Ontology (GO) function within GeneSpring. Biological themes that occurred in response to $\mathrm{BaP}$ through the cell cycle were thereby identified. The majority of functions identified indicate that the transcriptional response to $\mathrm{BaP}$ in MCF-7 cells in different phases is complex, with a large number of biochemical and molecular pathways being affected (Table 1).

In G1, genes involved in macromolecule metabolism were over-represented by four functional groups: macromolecule biosynthesis (10\%), positive regulation of metabolism (5\%) and transcription (4\%), and amino acid transport $(2 \%)$. These genes are involved in RNA transcription and protein synthesis and code for several ribosomal proteins (for example RPS10, RPS14, and RPS15A), solute carriers (SLC6A6, SLC7A11 and $S L C 6 A 14)$, and regulators of transcription (ATF4, JUN, EGR1, RSF and TRERF1). Other modulated genes belonged to cell differentiation (11\%) and cell proliferation (8\%) functional groups.

In $S$-phase, cell proliferation functional groups (7\%) were again identified including the genes $B T G 2, B T G 3$, GAS8 and HDAC4. Of these, BTG2 and BTG3 (both up-regulated) belong to a family of anti-proliferative genes. Genes involved in PAH metabolism were also over-represented and these included CYP1B1, AKR1C1, ALDH1A3 and UGT1A6.

In $G 2 / M$-phase, the largest functional groups identified were regulation of nucleic acid metabolism (24\%) and regulation of transcription (22\%), followed by cell differentiation (10\%) and cell cycle (10\%). Cell cycle regulation genes induced by BaP included NPM1, NBN, FHIT, CABLES2, ATF5, PCAF, CCNG1, RGC32, SESN1 and $B A X$. Signal transduction genes were represented by several functional groups such as small GTPasemediated signal transduction (6\%), MAPKKK cascade (3\%) and stress-related protein kinase signalling pathway (2\%).

\section{Pathway analysis of BaP-modulated genes}

The generated gene lists from GeneSpring were submitted to Ingenuity Pathway Analysis (IPA) and several interesting pathways and genes were revealed. Seven selected networks are presented here (Figure 5, 6 and 7 with Additional file 6); they are the top two scoring networks in each enriched culture and a third one for G2/ $M$-enriched cultures. This selection was based on the 
A

BaP-12 h

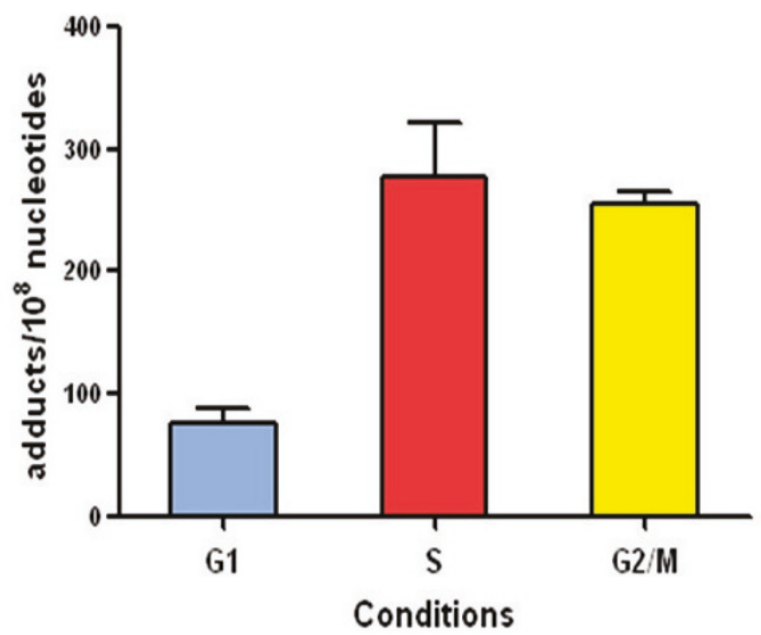

B

BPDE-12 h

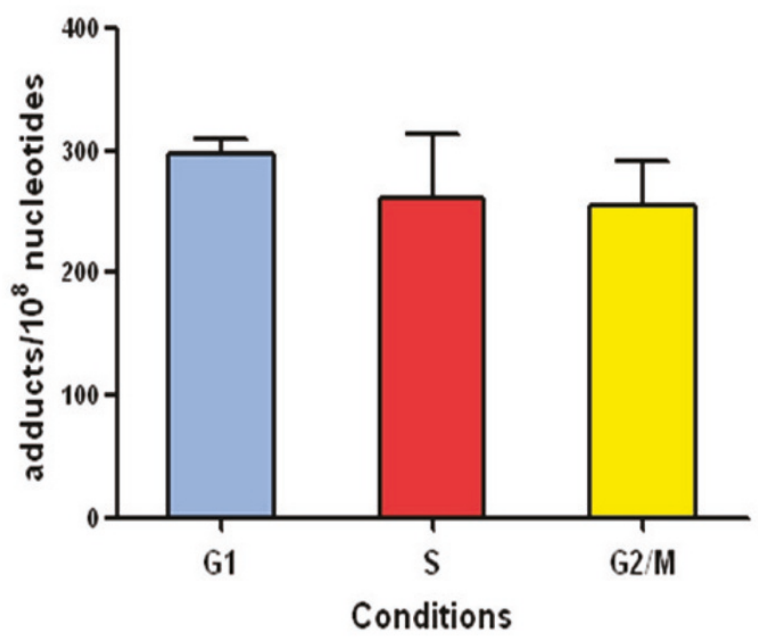

Figure 2 DNA adduct levels in synchronised MCF-7 cells. Cell were synchronised in G0/G1, S and G2/M phases with different methods, after which they were exposed to $2.5 \mu \mathrm{M} \mathrm{BaP}$ or $0.5 \mu \mathrm{M}$ BPDE for $12 \mathrm{~h}$. DNA was isolated with a standard phenol/chloroform method and DNA adducts were assessed by the ${ }^{32} \mathrm{P}$-postlabelling method. Results were expressed as DNA adducts $/ 10^{8}$ nucleotides.

ranking score within IPA, where networks with the highest number of significant changes rank highest in the list (a list of the top five scoring networks in each enriched culture is presented as supplementary data in Additional file 7). Several biological processes and signalling pathways were shown to be at the centre of $\mathrm{BaP}$ modulation, as described below.

G1-phase (Figure 5, Network A and B) Network 5A relates to the Catenin/Wnt pathway, which has a crucial role in embryonic development. Its deregulation can induce disease, most importantly cancer. One important gene in this pathway is CTNNB1, which stabilises $\beta$-catenin, a cytoplasmic protein that translocates into the nucleus and activates downstream genes such as MYC and cyclin D1, both of which regulate cell proliferation [14].

Network 5B involves mainly the JUN, EGR1 and ERK pathway. JUN, which is up-regulated in both G1- and $S$ phases, is an oncogene and a transcription factor that plays a role in the regulation of normal cell cycle progression [15]. EGR1 is another transcription factor that was up-regulated at the mRNA level in our study. It is at the crossroads of many signalling cascades. Many functions have been attributed to this protein, in particular its involvement in the control of cell growth, survival and transformation [16].

S-phase (Figure 6, Network A and B) JUN is again the focus of Network 6A and it is linked to several other genes, for example GDF15 and ATF3, both of which were up-regulated in the present study.
ATF3 is a member of the ATF/cyclic AMP response element-binding family of transcription factors. It has been proposed that it has a dichotomous role in cancer development by promoting or suppressing apoptosis and proliferation [17]. GDF15 is a member of the transforming growth factor $\mathrm{B}(T G F B)$ superfamily that regulates tissue differentiation and maintenance. It is also a transcriptional target of p53 [18]. Another interesting gene shown in this network is $N F \kappa B$, which promotes cell survival.

Network 6B shows mainly molecules that are involved in oxidative stress; NFE2L2 (NRF2) is induced in response to reactive oxygen species such as hydrogen peroxide. NRF2 plays a major role in the protective mechanism against xenobiotics capable of damaging DNA and initiating carcinogenesis. It is a cellular sensor of chemical- and radiation-induced oxidative and electrophilic stress, and a nuclear transcription factor that controls the expression and coordinated induction of a battery of defensive genes encoding detoxifying enzymes and antioxidant proteins. One of these proteins is NQO1 [19], which is mentioned in the Introduction.

G2/M-phase (Figure 7, Network A, B and C) Network 7A involves two pathways, Akt and apoptosis. Akt is a serine/threonine protein kinase that, when activated, plays a key role in mediating signals for cell growth, cell survival (anti-apoptotic), cell-cycle progression, differentiation, transcription, translation, and glucose metabolism. Recent advances in studying Akt signalling have 


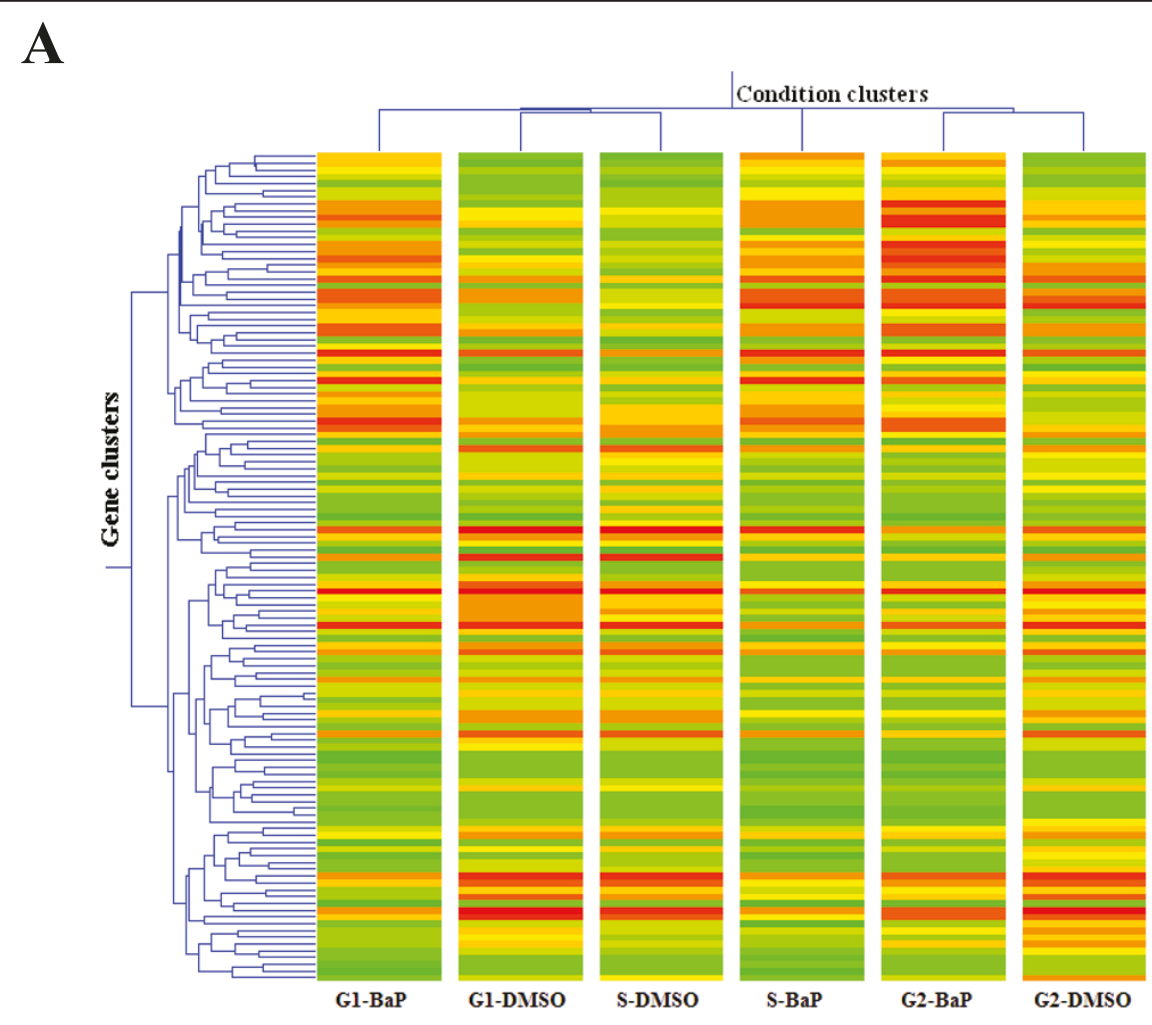

B

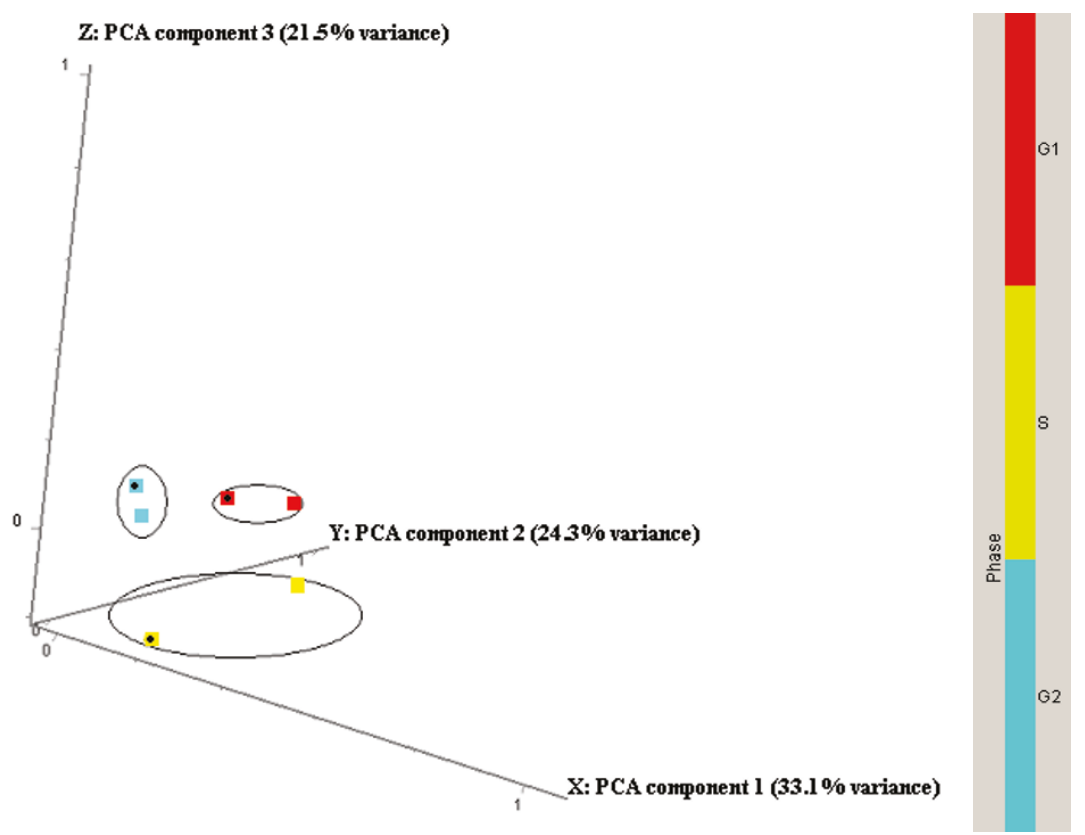

Figure 3 Cell cycle effects on microarray results. A- Hierarchical clustering of genes in different conditions; B- Principal component analysis (PCA). Both methods were performed in GeneSpring on a list of genes that had good confidence measurement and revealed a cell cycle response in gene expression profiles. Before BaP $(2.5 \mu \mathrm{M})$ treatment for $12 \mathrm{~h}$, MCF-7 cells were synchronised in different phases of the cell cycle. In hierarchical clustering (A), red colour denotes up-regulation and green denotes down-regulation. In PCA analysis (B), squares with black dots denote BaP-treated samples. 


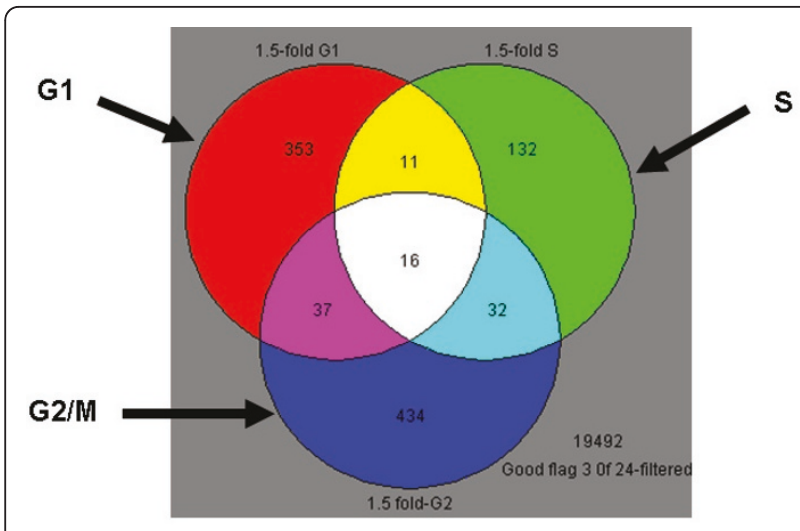

Figure 4 Venn diagram of the gene lists in different phases. Only genes that exhibited 1.5-fold or greater change after BaP treatment are shown. The gene lists represent expression profiles of MCF-7 cells synchronised in different phases of the cell cycle. Although there was overlap of the expression profiles between the phases, the majority of the changes were cell-cycle dependent.

uncovered important roles in $G 2 / M$ transition of the cell cycle where Akt activity is highest [20]. The NRF2 pathway is again central to Network $7 \mathrm{~B}$, which shows several genes involved in oxidative stress mechanisms such as NFE2L2, GSTM1, SLC7A11, and AHRR.

Network 7C was selected to be shown here because it has the important tumour suppressor TP53 at its centre along with several of its targets, confirming results obtained by gene ontology analysis. ASPM participates in the normal mitotic spindle function while $M B N L 2$ belongs to the muscleblind family that regulates alternative splicing. CABLES2 is a pro-apoptotic factor involved in p53-dependent or p53-independent apoptosis [21] while Scaper is a cyclin A-interacting protein that regulates cell cycle progression at the $G / S$ and $G 2 / M$ checkpoints [22].

\section{BaP-induced gene expression changes by RT-PCR}

RT-PCR is a more sensitive and specific measure of gene expression and was used to validate a number of key expression changes and to determine the reliability of the microarrays. Genes were selected for RT-PCR validation on the basis of: a) GeneSpring statistical analysis, b) gene ontology analysis and c) pathway analysis.

Genes validated by RT-PCR are shown in Table 2 . In the majority of cases there was a good correlation between RT-PCR and microarray results, RT-PCR being more sensitive; expression ratios were generally underestimated by microarray analysis. For $C Y P 1 A 1$, the correlation between the two methods was very low; no clear change in this transcript was evident from the microarrays, whereas $\mathrm{RT}-\mathrm{PCR}$ identified strong induction in all phases ranging from 74-fold in G2/M-enriched cultures to over 1800 -fold in $S$-enriched cultures (Figure 8 ). The failure of the microarrays to identify this gene expression change may be a result of very low basal levels of this transcript in this cell line, such that even if strongly induced, the microarrays are not sensitive enough to detect it. Another explanation could be the quality and specificity of the probe sequence in the array.

\section{Protein expression}

There was a clear induction of both CYP1A1 and CYP1B1 proteins after BaP exposure in all phases, but to a greater extent in $S$ - and G2/M- than in G1-enriched cultures (Figure 9). Band quantification showed that there was a 1.5-fold higher level of CYP1B1 in $S$ - and G2/M- than in G1-enriched cultures after BaP treatment. Similarly, the amount of CYP1A1 protein after $\mathrm{BaP}$ exposure was 5 to 6 -fold higher in $S$ - and $G 2 / M$ than in G1-enriched cultures. These findings correlate strongly with levels of DNA adducts seen in the different phases. There was a down-regulation of AHR after $\mathrm{BaP}$ treatment, as the protein levels were lower by 2fold in BaP-treated compared to DMSO control cells in all enriched cultures.

A number of TP53-regulated genes were modulated in response to $\mathrm{BaP}$ exposure at: a) the microarray level: STMN1 in G1 only; GDF15 and BTG2 in S only; PCAF, $B A X, S E S N 1, A S P M, M B N L 2, C A B L E S 2$ and Scaper in G2/M only; c-Jun and BTG3 in G1 and S; HINT1 and $R G C 32$ in $G 1$ and $G 2 / M$; b) the RT-PCR level: $C D K N 1 A, G D F 15$, and $R G C 32$ in all phases. Other genes that regulate TP53 activity, such as MDM4 and NPM1, were also modulated by BaP.

However, as expected, induction of TP53 gene expression was not observed on the microarrays and this was confirmed by RT-PCR. Therefore, p53 protein levels were assessed by Western blotting in order to confirm accumulation of this tumour suppressor in response to the $\mathrm{BaP}$ in different phases of the cell cycle (Figure 9). An increase in p53 protein was observed in MCF-7 cells after exposure to $\mathrm{BaP}$ in all phases with considerably more protein in $G 2 / M$-enriched cultures, underlying its significant role in the $G 2 / M$ checkpoint. These profiles of $\mathrm{p} 53$ protein activation are similar to those of its direct target CDKN1A (p21), except that there was no induction in $S$-enriched cultures (Figure 9).

\section{Discussion}

Microarray technology is a powerful tool for identifying gene expression patterns that are reflective of the response of cells to carcinogen exposure [23-25], and can be informative of mechanisms of action [26,27]. Using this technology we have investigated whether human cells are more susceptible to the environmental carcinogen $\mathrm{BaP}$ at particular phases of the cell 
Table 1 Biological processes significantly affected $(p<0.05)$ and over-represented after BaP treatment in synchronised MCF-7 cells in G0/G1, S, and G2/M as determined by Gene Ontology (GO) analysis within GeneSpring software

\begin{tabular}{|c|c|c|}
\hline Biological Process & $\%$ of Genes in List & p-Value \\
\hline \multicolumn{3}{|l|}{ G1-enriched cells } \\
\hline GO:7275: development & 26.4 & $1.50 \mathrm{E}-03$ \\
\hline GO:9653: morphogenesis & 11.8 & 1.60E-02 \\
\hline GO:30154: cell differentiation & 11.4 & $1.20 \mathrm{E}-02$ \\
\hline GO:9059: macromolecule biosynthesis & 10 & $1.10 \mathrm{E}-02$ \\
\hline GO:8283: cell proliferation & 8.6 & $1.90 \mathrm{E}-02$ \\
\hline GO:31325: positive regulation of cellular metabolism & 5 & $3.10 \mathrm{E}-02$ \\
\hline GO:45941: positive regulation of transcription & 4.1 & $4.90 \mathrm{E}-02$ \\
\hline GO:45321: immune cell activation & 3.2 & $2.30 \mathrm{E}-02$ \\
\hline GO:51606: detection of stimulus & 2.3 & 4.00E-03 \\
\hline \multicolumn{3}{|l|}{ S-enriched cells } \\
\hline GO:50789: regulation of biological process & 42.7 & 1.30E-02 \\
\hline GO:42127: regulation of cell proliferation & 7.3 & $2.10 \mathrm{E}-02$ \\
\hline GO:40007: growth & 5.5 & $1.70 \mathrm{E}-02$ \\
\hline GO:42592: homeostasis & 5.5 & $4.10 \mathrm{E}-02$ \\
\hline GO:45944: positive regulation of transcription from RNA polymerase II promoter & 3.6 & $2.20 \mathrm{E}-02$ \\
\hline GO:7420: brain development & 2.7 & 4.60E-02 \\
\hline GO:9065: glutamine family amino acid catabolism & 1.8 & $7.20 \mathrm{E}-03$ \\
\hline GO:6805: xenobiotic metabolism & 1.8 & $2.10 \mathrm{E}-02$ \\
\hline GO:9266: response to temperature stimulus & 1.8 & $2.10 \mathrm{E}-02$ \\
\hline GO:7157: heterophilic cell adhesion & 1.8 & $2.20 \mathrm{E}-02$ \\
\hline GO:6664: glycolipid metabolism & 1.8 & $2.70 \mathrm{E}-02$ \\
\hline GO:30203: glycosaminoglycan metabolism & 1.8 & 5.00E-02 \\
\hline GO:35026: leading edge cell differentiation & 0.9 & $5.60 \mathrm{E}-03$ \\
\hline GO:42268: regulation of cytolysis & 0.9 & $5.60 \mathrm{E}-03$ \\
\hline GO:46399: glucuronate biosynthesis & 0.9 & $1.10 \mathrm{E}-02$ \\
\hline GO:16264: gap junction assembly & 0.9 & $1.70 \mathrm{E}-02$ \\
\hline GO:6975: DNA damage induced protein phosphorylation & 0.9 & 1.70E-02 \\
\hline GO:48246: macrophage chemotaxis & 0.9 & $3.30 \mathrm{E}-02$ \\
\hline \multicolumn{3}{|l|}{ G2/M-enriched cells } \\
\hline GO:19219: regulation of nucleobase, nucleoside, nucleotide and nucleic acid metabolism & 23.9 & $1.40 \mathrm{E}-03$ \\
\hline GO:6355: regulation of transcription, DNA-dependent & 21.8 & $1.80 \mathrm{E}-02$ \\
\hline GO:30154: cell differentiation & 10.6 & $1.10 \mathrm{E}-02$ \\
\hline GO:7049: cell cycle & 9.9 & $2.70 \mathrm{E}-04$ \\
\hline GO:7264: small GTPase mediated signal transduction & 6.3 & $6.90 \mathrm{E}-03$ \\
\hline GO:9888: tissue development & 4.2 & 1.30E-02 \\
\hline GO:16337: cell-cell adhesion & 3.5 & $6.20 \mathrm{E}-03$ \\
\hline GO:165: MAPKKK cascade & 2.8 & $1.70 \mathrm{E}-02$ \\
\hline GO:31098: stress-activated protein kinase signaling pathway & 1.8 & $2.30 \mathrm{E}-03$ \\
\hline GO:8624: induction of apoptosis by extracellular signals & 1.4 & $3.70 \mathrm{E}-02$ \\
\hline GO:42551: neuron maturation & 1.4 & $3.00 \mathrm{E}-03$ \\
\hline GO:6986: response to unfolded protein & 1.4 & $1.10 \mathrm{E}-02$ \\
\hline GO:51259: protein oligomerization & 1.4 & $2.60 \mathrm{E}-02$ \\
\hline GO:9266: response to temperature stimulus & 1.1 & $1.50 \mathrm{E}-02$ \\
\hline
\end{tabular}




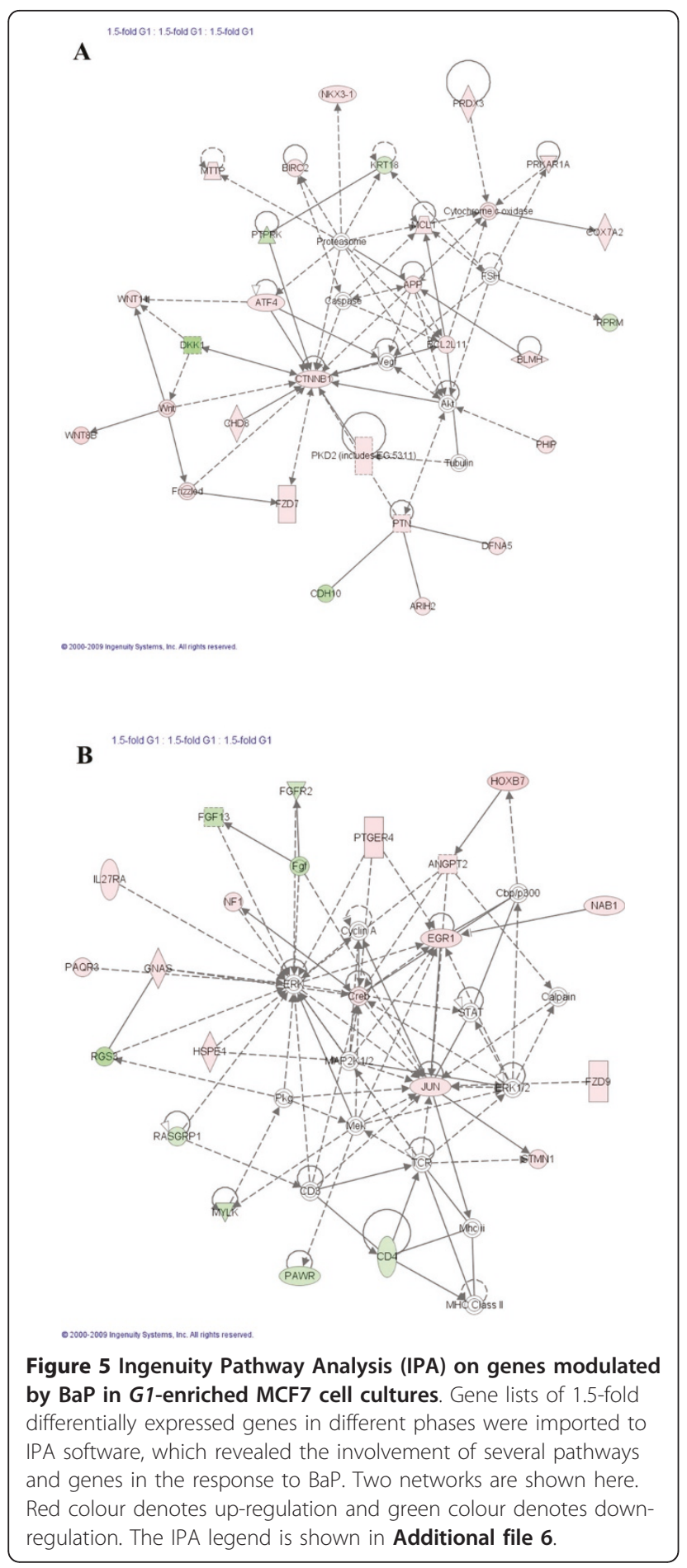

cycle and, if so, to elucidate the mechanisms involved. The resulting gene expression profiles were related to other phenotypic measures of $\mathrm{BaP}$ exposure such as DNA damage and cell cycle distribution to further our biological understanding of $\mathrm{BaP}$ carcinogenesis.
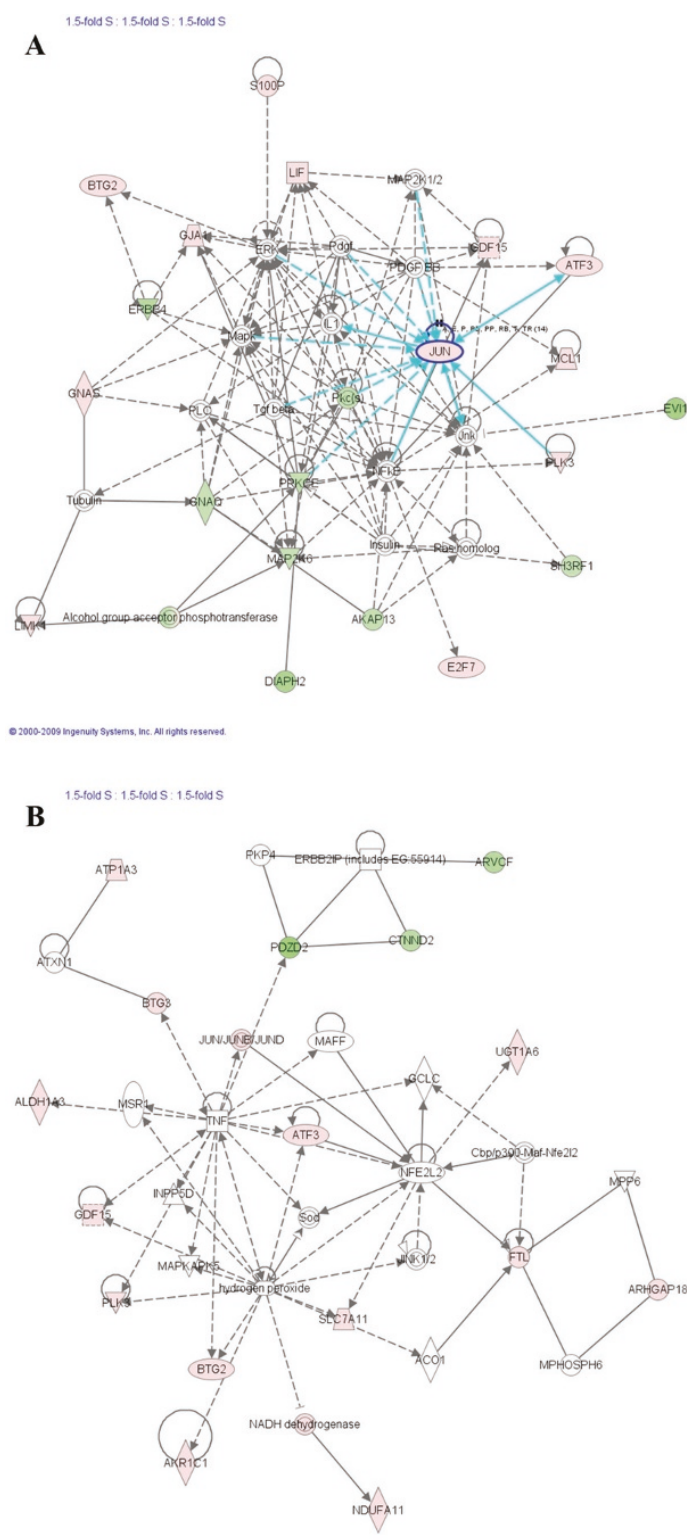

Figure 6 Ingenuity Pathway Analysis (IPA) on genes modulated by $\mathrm{BaP}$ in S-enriched MCF-7 cell cultures. Gene lists of 1.5 -fold differentially expressed genes in different phases were imported to IPA software, which revealed the involvement of several pathways and genes in the response to BaP. Two networks are shown here. Red colour denotes up-regulation and green colour denotes downregulation. The IPA legend is shown in Additional file 6 .

We found that $\mathrm{BaP}$ induced more DNA damage in synchronised MCF-7 cells enriched in $S$ - and G2/Mphases than in G1, which indicates that BaP is metabolised with varying efficiency at different stages of the cell cycle. This conclusion is supported by the fact that DNA damage induced by BPDE - which modifies DNA without further metabolism-, was not cell cycle 


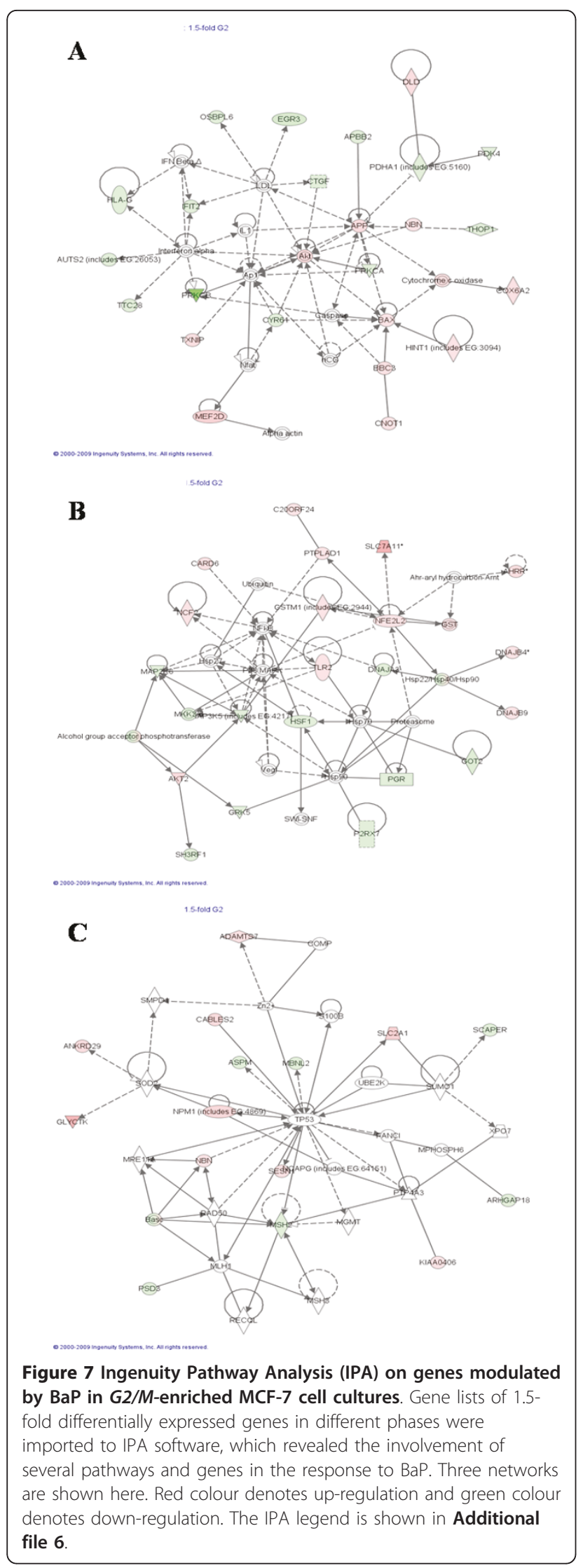

dependent. Gene expression profiling data (mRNA) and protein expression of xenobiotic metabolising enzymes further supported this hypothesis. Indeed, CYP1A1 mRNA measured by RT-PCR was almost 20-fold higher in $S$-phase than in G1 and G2/M. CYP1B1 mRNA followed the same pattern with a 2-fold higher induction in $S$-phase. Moreover, comparison between the levels of CYP1A1 in different phases revealed more mRNA in $S$ and $G 2 / M$-enriched cultures. The same pattern was observed at the protein level for CYP1A1 and CYP1B1. These findings correlate well with the levels of $\mathrm{BaP}$ DNA adducts at each phase of the cell cycle, consistent with the role of CYP1A1 and CYP1B1 in the metabolic activation of $\mathrm{BaP}$ to BPDE.

Previously, Jiao et al. [11] reported an up-regulation of CYP1A1 mRNA of $>100$-fold in BaP-treated $S$-enriched MCF-7 cultures, while up-regulation in G1- and G2/Menriched cultures occurred to a significantly lesser extent. Consistent with this, they also reported higher levels of DNA damage in the form of DNA single strand breaks and BaP-DNA adducts in $S$-enriched cultures. However, it is not the extent of induction that matters but the actual levels (absolute amounts) of mRNA and protein, because an apparently very strong induction could be due simply to very low basal levels. Moreover, Jiao and coworkers' BaP treatment was for $24 \mathrm{~h}$, a duration that is long enough for the cells to progress to another phase of the cell cycle. In another study, Santini et al. [13] showed that within $3 \mathrm{~h}$ of TCDD exposure late G1/early S-phase U937 human leukaemic monocyte lymphoma cells had 1.4- and 3-fold higher CYP1A1 mRNA levels than asynchronous/early $G 1$ and $G 2 / M$ cultures, respectively. In contrast, we found that the absolute mRNA levels of CYP1A1 and the protein levels of both CYP1A1 and CYP1B1 were actually higher in $S$ and $G 2 / M$-enriched cultures. AHR down-regulation at the protein level in all enriched cultures was the result of suppressing AHR signalling by rapid proteosomal degradation. Ligand-dependent receptor activation is well established, and several mechanisms capable of suppressing prolonged AHR signalling have been identified. These include rapid receptor degradation, the action of an AHR Repressor protein (AHRR), and agonist depletion through an enzymatic negative feedback loop [28]. AHR activation independent of agonist binding in mammalian systems has been proposed, but evidence for it is not yet conclusive. Chang and Puga [29] reported that AHR-dependent effects on cell proliferation could be dissociated from exogenous ligand binding. In another study, cell density, but not cell cycle, was shown to influence the intracellular distribution of AHR [30]. However, neither study established the absence of an endogenous ligand responsible for receptor activity. 
Table 2 A summary of gene expression changes induced by BaP in MCF7 cells using microarray and RT-PCR analysis

\begin{tabular}{|c|c|c|c|c|c|c|c|}
\hline \multirow[b]{2}{*}{ Gene Symbol } & \multirow[b]{2}{*}{ Biological function } & \multicolumn{2}{|c|}{ Change in G1 } & \multicolumn{2}{|l|}{ Change in $S$} & \multicolumn{2}{|c|}{ Change in $G 2 / M$} \\
\hline & & RT-PCR & Microarrays & RT-PCR & Microarrays & RT-PCR & Microarrays \\
\hline CYP1A1 & Xenobiotic metabolism & $\uparrow 91.5$-fold & - & $\uparrow 1866.8$-fold & - & $\uparrow 73.7$-fold & - \\
\hline$\overline{C Y P 1 B 1}$ & Xenobiotic metabolism & $\uparrow 19$-fold & $\uparrow 2.7$-fold & $\uparrow 40.4$-fold & $\uparrow 3.2$-fold & $\uparrow 21.9$-fold & $\uparrow 2.3$-fold \\
\hline GDF15 & Cell differentiation & $\uparrow 11.2$-fold & - & $\uparrow 22.5$-fold & $\uparrow 8.9$-fold & $\uparrow 2$-fold & - \\
\hline$\overline{T I P A R P}$ & PARP family & $\uparrow 5.5$-fold & - & $\uparrow 5.8$-fold & $\uparrow 2.9$-fold & $\uparrow$ 6-fold & $\uparrow 4.7$-fold \\
\hline$\overline{J U N}$ & Cell proliferation & $\uparrow 5.5$-fold & $\uparrow 1.8$-fold & $\uparrow 5.1$-fold & $\uparrow 3.6$-fold & - & - \\
\hline$p 21$ & cell cycle checkpoints & $\uparrow 3.2$-fold & - & $\uparrow 6.6$-fold & - & - & - \\
\hline RASAL1 & Ras regulator & $\uparrow 3.4$-fold & - & $\uparrow 2.8$-fold & $\uparrow 3.3$-fold & - & $\downarrow 2.8$-fold \\
\hline RGC32 & Cell cycle control & $\uparrow 2.9$-fold & $\uparrow 1.6$-fold & $\uparrow 2.3$-fold & - & $\uparrow 2.3$-fold & $\uparrow 1.5$-fold \\
\hline ALDH1A3 & Xenobiotic metabolism & $\uparrow 1.7$-fold & - & $\uparrow 4.2$-fold & $\uparrow 4.3$-fold & $\uparrow 2.4$-fold & - \\
\hline$D L X 2$ & Development & $\uparrow 1.5$-fold & - & $\uparrow 4.8$-fold & $\uparrow 5$-fold & $\uparrow 2.5$-fold & $\uparrow 3.3$-fold \\
\hline$\overline{C E B P A}$ & Mitotic growth arrest & $\uparrow 1.7$-fold & - & - & - & $\uparrow 1.5$-fold & $\uparrow 1.7$-fold \\
\hline NRF2 & Oxidative stress & $\uparrow 1.5$-fold & - & - & - & $\uparrow 1.6$-fold & $\uparrow 1.6$-fold \\
\hline$\overline{\text { ATF3 }}$ & Transcription Factor & $\uparrow 3$-fold & - & $\uparrow 6.1$-fold & $\uparrow 4.5$-fold & - & \\
\hline DNAJB4 & Oxidative stress & $\uparrow 2.2$-fold & - & $\uparrow 1.6$-fold & $\uparrow 1.9$-fold & - & $\uparrow 1.5$-fold \\
\hline Bax & Apoptosis & $\uparrow 1.5$-fold & - & $\uparrow 1.6$-fold & - & - & $\uparrow 1.6$-fold \\
\hline$\overline{S P R Y 4}$ & MAPK signalling & - & - & - & $\uparrow 4.5$-fold & $\uparrow 1.7$-fold & - \\
\hline$\overline{\text { GSTT2 }}$ & Xenobiotic metabolism & $\uparrow 2.8$-fold & $\uparrow 1.7$-fold & - & - & - & - \\
\hline CABLES2 & Apoptosis & - & - & - & - & - & $\uparrow 2.3$-fold \\
\hline PTGER4 & T-cell factor signalling & - & $\uparrow 2.7$-fold & $\uparrow 1.5$-fold & - & - & $\uparrow 2.2$-fold \\
\hline$B B C 3$ & Apoptosis & - & - & $\uparrow 2.1$-fold & $\uparrow 5$-fold & - & $\uparrow 1.9$-fold \\
\hline EGR1 & Cell growth and proliferation & $\uparrow 6.7$-fold & $\uparrow 2.7$-fold & $\uparrow 2.5$-fold & - & - & - \\
\hline CTNNB1 & Cell adhesion & $\uparrow 1.5$-fold & $\uparrow 2.25$-fold & - & - & - & - \\
\hline$P L K 3$ & Cell cycle control & - & - & $\uparrow 2.5$-fold & $\uparrow 3.4$-fold & - & - \\
\hline$\overline{A F F 4}$ & Transcription Elongation & - & - & - & $\downarrow 2.6$-fold & $\downarrow 1.5$-fold & $\downarrow 6.2$-fold \\
\hline ZBRK1 & DNA damage response & - & - & - & $\downarrow 4.7$-fold & - & - \\
\hline DKK1 & Wnt/Catenin & $\downarrow$ 7-fold & $\downarrow 3.1$-fold & $\downarrow 2.8$-fold & - & $\downarrow 2.4$-fold & - \\
\hline KAT2B & Transcription regulation & $\downarrow 4$.6-fold & - & $\downarrow$ 3-fold & - & $\downarrow 6.5$-fold & $\downarrow 1.7$-fold \\
\hline RASGRP1 & Ras signalling & $\downarrow 3.8$-fold & $\downarrow 1.5$-fold & $\downarrow 2$.2-fold & - & $\downarrow$ 6-fold & $\downarrow$ 2-fold \\
\hline JMJD2C & Histone demethylase & $\downarrow$ 3.6-fold & - & $\downarrow 4.5$-fold & $\downarrow$ 2-fold & $\downarrow$ 3-fold & $\downarrow 1.8$-fold \\
\hline HDAC4 & Cell cycle control & $\downarrow 2.1$-fold & - & $\downarrow 2.7$-fold & $\downarrow 1.8$-fold & $\downarrow 1.8$-fold & - \\
\hline FERMT1 & Actin cytoskeleton & $\downarrow 2.1$-fold & $\downarrow$ 6.7-fold & $\downarrow 1.8$-fold & - & $\downarrow 2.5$-fold & - \\
\hline Scaper & cell cycle checkpoints & $\downarrow 1.8$-fold & $\downarrow 1.5$-fold & $\downarrow 1.8$-fold & $\downarrow$ 2-fold & $\downarrow 2$.8-fold & $\downarrow 2.2$-fold \\
\hline NPM1 & Cell proliferation/Apoptosis & - & - & - & - & - & $\uparrow 2.4$-fold \\
\hline YWHAQ & Cell cycle control/Apoptosis & - & - & - & - & - & - \\
\hline$A H R$ & Xenobiotic Metabolism & - & - & - & - & - & - \\
\hline$p 53$ & Tumour Suppressor & - & - & - & - & - & - \\
\hline RFC5 & Replication Factor & - & $\uparrow 1.8$-fold & - & - & - & - \\
\hline Hint1 & Apoptosis & - & $\uparrow 2.2$-fold & - & - & - & $\uparrow 1.5$-fold \\
\hline NQO1 & Xenobiotic metabolism & - & $\uparrow 2.2$-fold & - & - & - & - \\
\hline
\end{tabular}

A 1.5 -fold cut-off was used. $\uparrow$ denotes up-regulation, and $\downarrow$ denotes down-regulation.

Preliminary experiments have indicated that there are no differences in BaP-DNA adduct formation between G0- and G1-enriched MCF-7 cultures (data not shown). Therefore, adduct levels in G0- are lower than $S$ - and $G 2 / M$-enriched cultures. GO cells are quiescent i.e. not cycling, as is the case with many cell types in mammalian tissues. Interpreting the adduct data in the light of this information could point to a difference in susceptibility to genotoxic carcinogens between proliferating (cycling cells that go beyond G1 


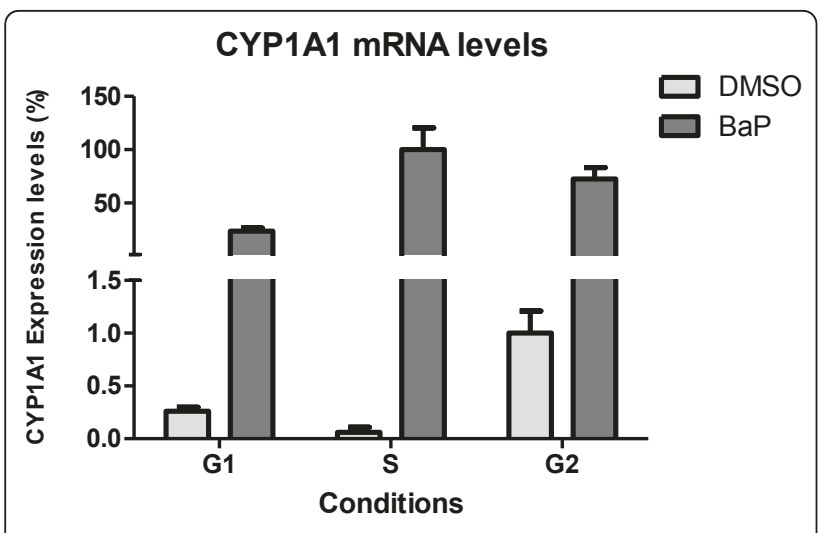

Figure 8 Relative CYP1A1 mRNA expression levels in synchronised MCF7 cells with and without BaP treatment. mRNA quantification was carried out by RT-PCR. The highest expressed sample in the RT-PCR was set to $100 \%$ and other samples' expressions are shown relative to that. Values represent mean \pm SD from 3 determinations.

to $S$, and $G 2 / M$ ) and non-proliferating cells (mainly in G0).

BaP exposure resulted in an arrest of the cells in $S$ phase of the cell cycle in $S$ - and $G 2 / M$-enriched cultures, indicating that interruption of DNA synthesis had occurred. This is in agreement with other studies that have shown the inhibition of DNA synthesis in response to $\mathrm{BaP}[9,31]$. The pause in DNA synthesis is probably due to the intra- $S$ checkpoint, which allows repair enzymes time to recognize the damaged DNA and to correct it, avoiding irreversible errors during replication (i.e. mutations). Alternatively, a permanent growth arrest

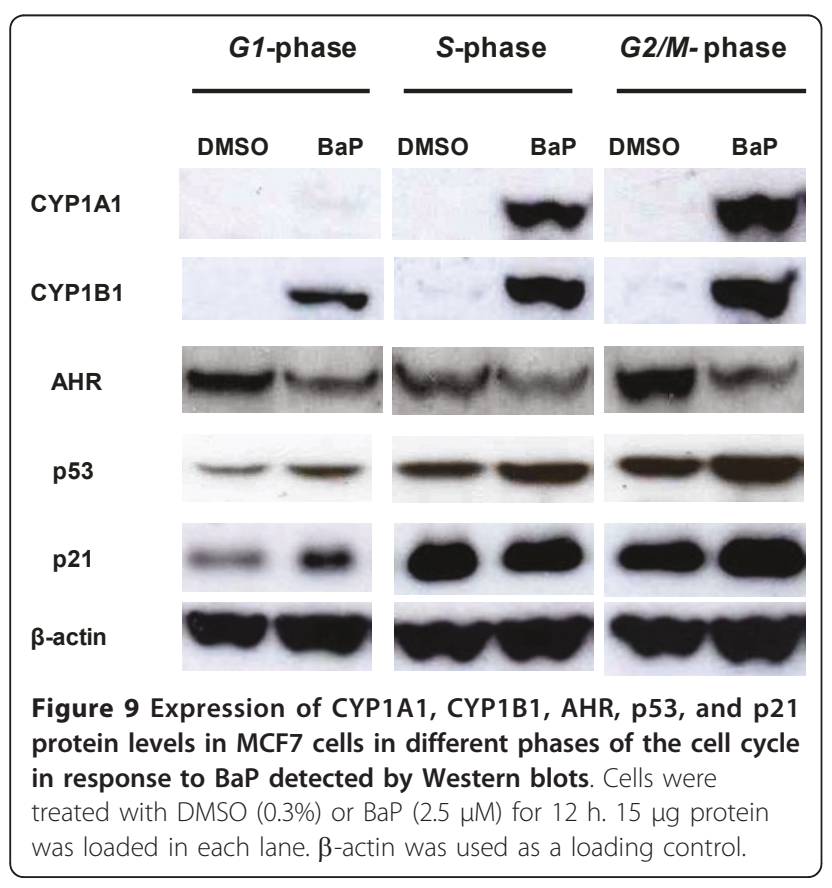

or apoptosis can be initiated if damage is too great or persists for too long [32].

We found that BaP did not activate the G1/S checkpoint despite p53 and p 21 protein induction in these phases. The G1 arrest delays DNA damaged cells from progressing through the cell cycle, avoiding accumulation of mutations and chromosomal aberrations by means of DNA repair or apoptosis. TP53 and its transcriptional target $C D K N 1 A$ ( $p 21)$ contribute to G1 and G2 arrest in response to DNA damage to maintain genomic stability [33]. These responses consist of the ATM(ATR)/CHK2(CHK1)-p53/MDM2-p21 pathway, which is capable of sustaining G1 arrest. Phosphorylation of p53 transcription factor and MDM2 (which normally binds to p53 and ensures rapid p53 turnover) results in p53 stabilisation and accumulation. p21, in turn, inhibits cyclin $\mathrm{E}(\mathrm{A}) / \mathrm{CDK} 2$ and preserves the $\mathrm{RB} /$ E2F pathway in its active, growth-suppressing mode [32,34,35].

In one study, Khan and Dipple [7] showed that following treatment with a range of agents, including metabolites of BaP, G1 arrest does not occur in MCF-7 cells and other cell lines. They also demonstrated that BPDE is not effective in arresting MCF-7 cells in G1 in spite of inducing dose-dependent increases in p53 and p21 [36]. The ability of carcinogens to induce cells to evade the G1 DNA-damage checkpoint and progress into $S$ phase is known as the stealth property. This property presumably enhances the mutation frequency and increases the likelihood of malignant changes.

In another study, Jiao et al. [37] investigated the mechanisms by which $\mathrm{BaP}$ accelerates cell cycle progression (G1/S transition) and induces cell proliferation in human embryo lung fibroblasts. They also found that cJun activation (by phosphorylation) by p53-dependent $\mathrm{PI}-3 \mathrm{~K} / \mathrm{Akt} / \mathrm{ERK}$ pathway might be responsible for BaPinduced cell cycle alterations. Interestingly, JUN mRNA was up-regulated by BaP in our study in both G1- and $S$-enriched cultures. In addition to that, our pathway analysis showed it to be significantly involved in Network 5B (G1-enriched cells) and Network 6A (Senriched cells).

Gene Ontology analysis revealed several over-represented biological themes after BaP exposure. These include cell differentiation, cell proliferation, cell cycle regulation and xenobiotic metabolism. In G1-enriched cultures, some modulated genes belonged to cell differentiation (11\%) and cell proliferation (8\%) functional groups. One of these genes is BTG3 (up-regulated), which has been identified as a DNA damage-inducible CHK1-modulated gene. As it is a direct p53 target this emphasises its importance in cell cycle regulation and in maintaining genome stability [38]. Another example of modulated genes involved in regulating cell proliferation 
and differentiation is $E G R 1$, which was also revealed by pathway analysis (Network 5B in G1-enriched cells). Modulation of the expression of this gene was validated by RT-PCR and it was shown to be induced in G1-, and $S$-enriched cultures. Several xenobiotic metabolism genes were also modulated by BaP, including CYP1B1, GSTT2 and NQO1. Detoxification of PAH quinone metabolites is carried out by $\mathrm{NAD}(\mathrm{P}) \mathrm{H}$ :quinone oxidoreductase encoded by NQO1 [39], which is also required for p53 stabilisation in response to DNA damage [40]. Glutathione S-transferase T2 (GSTT2) is involved in cellular defence against toxic and carcinogenic electrophilic compounds by conjugation of reduced glutathione to hydrophobic electrophiles [41], so it was a logical finding that GSTT2 was up-regulated in response to $\mathrm{BaP}$ exposure.

Pathway analysis revealed the activation of the Catenin/Wnt pathway (Network $5 \mathrm{~A}$ ) in the response to $\mathrm{BaP}$ exposure. Consistent with this, RT-PCR analysis showed that $D K K 1$ (a Wnt antagonist) was down-regulated (by 7-fold) in G1-enriched cultures and CTNNB1 was upregulated (by 1.4-fold) in the same cultures.

In $S$-phase, cell proliferation and apoptosis genes such as BTG2 and HDAC4 were also differentially expressed. Previously, our team showed that BTG2 was up-regulated by BaP and BPDE at different time points in MCF-7 cells $[9,10]$. Its expression was also shown to be induced by genotoxic stress through a p53-dependent mechanism [42]. HDAC4, which encodes a histone deacetylase that represses transcription and regulates differentiation, was down-regulated in our experiments [43]. Differentially expressed genes involved in $\mathrm{PAH}$ metabolism included CYP1B1, AKR1C1, ALDH1A3 and UGT1A6. CYP1B1 (also induced in G1- and G2/M-enriched cultures) encodes a member of the CYP superfamily of monooxygenases and is involved in the metabolic activation of $\mathrm{BaP}[44,45]$. Interestingly, enhanced expression of this enzyme has been observed in a number of cancers $[46,47]$ and it has been demonstrated, in experiments involving CYP1B1-null mice, that it enhances the carcinogenicity of 7,12-dimethylbenz[a] anthracene [48]. CYP1B1 has also been found to be up-regulated in primary human mammary epithelial cells exposed to BaP, highlighting the importance of this enzyme in $\mathrm{BaP}$ metabolism in this tissue [49]. Consistent with previous studies [9,50], AKR1C1 was also found to be up-regulated by $\mathrm{BaP}$. It encodes an aldo-keto reductase capable of metabolising PAH trans-dihydrodiols to $o$-quinones that can lead to the formation of DNA adducts and reactive oxygen species (ROS) [50,51], thus providing another pathway of PAH genotoxicity. UGT1A6 is involved in glucuronidation, which is a major pathway for detoxification of PAH metabolites [52].
Another interesting gene function category revealed by the transcriptomic analysis was that of DNA-damage induced protein phosphorylation, as exemplified by MAP2K6. This gene encodes a member of the dual specificity protein kinase family, which functions as a mitogen-activated protein (MAP) kinase kinase. MAP kinases, also known as extracellular signal-regulated kinases (ERKs), act as an integration point for multiple biochemical signals. This protein phosphorylates and activates p38 MAP kinase in response to inflammatory cytokines or environmental stress. As an essential component of the p38 MAP kinase signal transduction pathway, MAP2K6 is involved in many cellular processes such as stress-induced cell cycle arrest, transcription activation and apoptosis [53].

In $G 2 / M$-phase, $\mathrm{BaP}$ altered the expression of several cell cycle regulation genes, including NPM1, PCAF, $N B N, R G C 32, S E S N 1$ and $B A X$ as shown by Gene Ontology and pathway analysis (Table 1 and Network 7C). NPM1 (up-regulated) has been shown to be implicated in human tumourigenesis, functioning both as an oncogene and as a tumour-suppressor. It is involved in many pathways such as cell cycle control, DNA repair and apoptotic response to stress by modulating the activity and stability of critical tumour-suppressor proteins such as p53 [54]. NBN (up-regulated) is involved in cell cycle checkpoints in response to DNA damage [55]. RGC32, SESN1 and BAX (all up-regulated) are all targets of p53 contributing to its role in cell cycle regulation, metabolism and apoptosis [56-58]. Indeed, accumulation of p53 was seen after BaP treatment by Western blotting (Figure 9).

\section{Conclusions}

Exposure of synchronized MCF-7 cells to BaP has identified a complex gene expression response by microarray analysis. A number of genes were found to have their expression altered by $\mathrm{BaP}$, including those involved in xenobiotic metabolism, apoptosis, cell cycle regulation and DNA repair. Gene ontology and pathway analysis showed the involvement of various signalling pathways in the response to BaP, such as Catenin/Wnt pathway in G1, ERK pathway in $G 1$ and $S$, Nrf2 pathway in $S$ and $G 2 / M$ and Akt pathway in $G 2 / M$.

A key finding in this study was that higher levels of DNA adducts in $S$ - and G2/M-enriched cultures correlated with higher levels of CYP1A1 and CYP1B1 mRNA and protein expression, indicating that proliferating cells are more prone to DNA damage by genotoxic stress than non-proliferating cells. Our results clearly demonstrate that this is due to the varying efficiency of $\mathrm{BaP}$ metabolism through the cell cycle. Additional studies with other cells lines and genotoxic agents will be 
required to determine whether our findings, in terms of adduct formation and expression of CYP1A1 and CYP1B1 (both at the mRNA and protein level) are universal or specific to certain cell types.

\section{Methods}

\section{Cell culture and treatment}

MCF-7 human breast carcinoma cells were purchased from the European Collection of Cell Cultures (ECACC, Salisbury, UK). Cells were grown as adherent monolayers and maintained in Dulbecco's modified Eagle's medium with Glutamax ${ }^{\mathrm{TM}} \mathrm{I}, 1000 \mathrm{mg} / \mathrm{L} \mathrm{D}$-glucose and sodium pyruvate (Invitrogen, Paisley, UK) and supplemented with $10 \%$ heat-inactivated foetal bovine serum (Invitrogen) and $100 \mathrm{U} / \mathrm{mL}$ penicillin and $100 \mu \mathrm{g} / \mathrm{mL}$ streptomycin (Sigma-Aldrich, Dorset, UK). Cells were incubated in a humidified $5 \% \mathrm{CO}_{2}$ atmosphere at $37^{\circ} \mathrm{C}$ and sub-cultured every $72 \mathrm{~h}$ when the cells were $80 \%$ confluent.

Culture conditions were manipulated in order to generate (1) G0/G1-enriched cultures by serum deprivation for $48 \mathrm{~h}$ (cells were kept in $G 0$ by not adding the serum back during the BaP treatement in contrast to G1enriched cells); (2) $S$-enriched cultures by serum deprivation for $48 \mathrm{~h}$ followed by $18 \mathrm{~h}$ growth in complete media; and (3) G2/M-enriched cultures by treatment for $24 \mathrm{~h}$ with $1 \mu \mathrm{g} / \mathrm{mL}$ aphidicolin followed by $0.25 \mu \mathrm{M}$ colchicine for $12 \mathrm{~h}$. Cell cycle distributions, determined by flow cytometry are shown in Table 3 .

Cells were seeded at $2 \times 10^{5}$ cells $/ \mathrm{ml}$ and treated with $\mathrm{BaP}(2.5 \mu \mathrm{M})$, and BPDE $(0.5 \mu \mathrm{M})$ for 12 hours. DMSO only was added to control cultures and its volume was kept at $0.3 \%$ of the total culture volume. Cells were harvested by trypsinisation followed by washing with PBS. All cell incubations for the different experimental applications were carried out in duplicate or triplicate.

\section{Flow cytometry}

Harvested cells were re-suspended in $0.2 \mathrm{~mL} \mathrm{10X} \mathrm{PBS}$ solution and fixed in $2 \mathrm{~mL}$ of ice-cold $70 \%$ ethanol. Samples were then stored at $-20^{\circ} \mathrm{C}$ overnight. Twenty four hours prior to flow cytometry analysis, samples were centrifuged at $1500 \times$ g for 5 minutes and resuspended in staining buffer containing $40 \mu \mathrm{g} / \mathrm{mL}$ propidium iodide (Invitrogen), $100 \mu \mathrm{g} / \mathrm{mL}$ RNase (Qiagen, UK) in PBS buffer at a final density of $1 \times 10^{6}$ cells/ $\mathrm{mL}$. Cells were then incubated at $37^{\circ} \mathrm{C}$ for 60 minutes and stored at $4^{\circ} \mathrm{C}$ overnight. The DNA content of 10,000 events per sample was analysed using a Beckman Coulter EPICS Elite ESP (Beckman Coulter, Buckinghamshire, UK) at $488 \mathrm{~nm}$. The percentage of cells in each phase of the cell cycle was determined using Cylchred v1.0.2 and WinMDI v2.8 software [59]. Differences between control and treated cells were examined for statistical significance using Student's $t$-test (two-tailed).

\section{Cell viability}

Cell viability (\% control) was determined by cell counting with the CASY Model TT Electronic Cell Analyser (Innovatis AG, Germany).

\section{DNA adduct analysis}

DNA was isolated from cell pellets by a standard phenol chloroform extraction method. DNA was quantified spectrophotometrically and DNA adducts were determined for each DNA sample using the nuclease P1 enrichment version of ${ }^{32} \mathrm{P}$-postlabelling method [60]. Briefly, DNA samples $(4 \mu \mathrm{g})$ were digested with micrococcal nuclease (120 mU, Sigma, UK) and calf spleen phosphodiesterase (40 mU, Calbiochem, UK), then enriched and labelled as reported. Solvent conditions for the resolution of ${ }^{32} \mathrm{P}$-labelled adducts on polyethyleneimine-cellulose thin-layer chromatography (TLC) were as described [9]. After chromatography TLC plates were scanned using a Packard Instant Imager (Dowers Grove, IL, USA) and DNA adduct levels (RAL, relative adduct labelling) were calculated from the adduct cpm, the specific activity of $\left[\gamma_{-}{ }^{32} \mathrm{P}\right] \mathrm{ATP}$ and the amount of DNA (pmol of DNA-P) used. Results were expressed as DNA adducts $/ 10^{8}$ nucleotides. An external BPDE-DNA standard [61] was employed for identification of adducts in experimental samples.

\section{RNA isolation and whole-genome gene expression profiling}

Total RNA was extracted from cells using the Qiagen RNeasy Mini Kit protocol (RNeasy Mini Handbook, Qiagen, UK). RNA was quantified spectrophotometrically, and integrity was determined using a 2100 Bioanalyser (Agilent Technologies, UK). Only RNA with an integrity number $\geq 9$ was used for gene expression analysis.

Table 3 Cell cycle distribution of MCF-7 cells prior to BaP treatment

\begin{tabular}{lllll}
\hline & & \multicolumn{2}{l}{ Cell cycle distribution (\%) } \\
\hline Culture manipulations (time, $\mathbf{h})$ & G0/G1-phase & S-phase & G2/M-phase \\
\hline G0/G1-enriched & $48 \mathrm{~h}$ serum deprivation & $65.3 \pm 2.1$ & $14.1 \pm 2.4$ & $20.6 \pm 2.4$ \\
\hline S-enriched & $18 \mathrm{~h}$ after $48 \mathrm{~h}$ serum deprivation & $24.7 \pm 4.2$ & $55.7 \pm 8.2$ & $19.5 \pm 4.0$ \\
\hline G2/M-enriched & $12 \mathrm{~h}$ colchicine $(0.25 \mu \mathrm{M})$ after $24 \mathrm{~h}$ aphidicolin $(1 \mu \mathrm{g} / \mathrm{mL})$ & $8.9 \pm 2.2$ & $18.2 \pm 4.1$ & $72.9 \pm 5.9$ \\
\hline
\end{tabular}

Cells were manipulated to generate: GO/G1-, S-, and G2/M-enriched cultures. 
Gene expression analysis was carried out using the Agilent two-colour microarray-based gene expression analysis (Agilent Technologies, UK), which uses cyanine 3 (Cy3)- and cyanine 5 (Cy5)-labelled targets to measure gene expression in experimental and control samples.

Agilent Human $4 \times 44 \mathrm{~K}$ Genome-wide arrays were used and the reference design was applied, whereby a Universal Human Reference RNA (Stratagene, La Jolla, USA) was hybridised to every sample. Cy3-(sample)and Cy5-(reference)-labelled probes were hybridised to the oligo microarrays using the Gene Expression Hybridization Kit (Agilent Technologies, UK) using Agilent SureHyb chambers for 17 hours in Rotisserie Hyb Oven set to $65^{\circ} \mathrm{C}$ (Agilent) and rotating at $10 \mathrm{rpm}$. The array slides were washed according to the manufacturer's instructions (Agilent) and dried with compressed air prior to scanning on an Axon B400 Scanner (Axon, Instruments, USA).

\section{Microarray data analysis}

The multi-image TIFF files generated by the scanner were exported to BlueFuse software, which adjusts the initial grid position and optimises spot finding in the image automatically so that each spot on the array is assigned a specific gene. BlueFuse software generated Excel files, which were analysed using GeneSpring v7.2 software (Silicon Genetics).

Data were imported into GeneSpring software and subjected to Per chip and Per spot lowess normalisation. Bad spots that were flagged in BlueFuse software were filtered out in order to give a gene list of reliable data. Cy3/Cy5 ratios of the 3 biological replicates were averaged and then used to identify modulated genes using 1 Way-ANOVA with a cut-off of 1.5 -fold change and a Student's $t$-test $p$-value of less than 0.05 . Over-representation analysis of differentially expressed genes was carried out using the Gene Ontology function within GeneSpring and Ingenuity pathway software.

The gene expression data discussed in this publication have been deposited in NCBI Gene Expression Omnibus [62] and are accessible through GEO Series accession number GSE26917.

\section{Real-time quantitative PCR}

Two-step reverse transcription-PCR was used to generate cDNA for relative quantitation analysis using real-time fluorescent PCR. cDNA was reversed transcribed from 1 $\mu \mathrm{g}$ total RNA using random primers following the Superscript III Reverse Transcriptase First-Strand cDNA Synthesis Protocol (Invitrogen). cDNA was diluted 1:10 and $2 \mu \mathrm{L}$ was used as template to perform RT-PCR in a $15 \mu \mathrm{L}$ reaction. GAPDH was used as an endogenous control (Applied Biosystems, UK) in multiplexed PCR reactions on an ABI PRISM 7900HT Sequence Detection
System (Applied Biosystems) with standard thermocycling conditions $\left(50^{\circ} \mathrm{C} 2 \mathrm{~min}, 95^{\circ} \mathrm{C} 10 \mathrm{~min}\right.$, then 40 cycles of $95^{\circ} \mathrm{C} 15 \mathrm{~s}, 60^{\circ} \mathrm{C} 1 \mathrm{~min}$ ), using Taqman Universal PCR Master Mix (Applied Biosystems). To confirm the modulated expression of the selected target genes, 20x AssaysOn-Demand ${ }^{\mathrm{TM}}$ gene expression primers and probes (Applied Biosystems) were used. The list of the assays is provided as Additional file 8. Relative gene expression between the control (or calibrator) and treated samples was calculated after normalisation to the GAPDH reference using the comparative threshold cycle $\left(\mathrm{C}_{\mathrm{T}}\right)$ method.

\section{Western blot analysis}

Cells were lysed in $800 \mu \mathrm{L}$ lysis buffer $(62.5 \mathrm{mM}$ Tris pH 6.8, 1 mM EDTA pH 8.0, 2\% SDS, 10\% Glycerol). Samples were sonicated to break up the DNA and their protein concentration was determined using the BCA assay (Piercenet, UK) in order to load the same amounts of protein. Cell lysates were electrophoretically separated using Criterion XT 4-12\% Bis-Tris gels (Bio-Rad, UK). Following electrophoresis, gels were transferred onto a nitrocellulose membrane (Millipore, UK). Ponceau staining was performed to check for the quality of transfer, and then the membranes were blocked by incubation in $5 \%$ non-fat dry milk dissolved in TBST overnight at $4{ }^{\circ} \mathrm{C}$. Blots were then incubated with primary antibody, thereafter with the species-specific horseradish peroxidaseconjugated secondary antibody and bands detected by chemiluminescence (ECL detection reagents, GE Healthcare). The following primary antibodies were purchases: anti-p53 (Ab-6; 1:2,000) from Calbiochem (Darmstadt, Germany), anti-p21 (BD 556431; 1:2,000) from BD Science (Oxford, UK), anti-CYP1B1 (CYP1B11-A; 1:2,000) from Alpha Diagnostic (Hampshire, UK), antiAHR (Abcam ab2770; 1:1,000). Anti-CYP1A1 raised in rabbits against purified human recombinant CYP1A1 was a generous gift from F. Peter Guengerich (Vanderbilt University, USA) and was diluted 1:4,000. The antibody to detect $\beta$-actin (Ab6276; 1:25,000) was purchased from Abcam and used as a loading control. Two secondary horseradish peroxidise-linked antibodies were purchased: anti-mouse (CST 7076; 1:10,000), antirabbit (CST 7074; 1:10,000) from Cell Signalling Technologies (Herts, UK). Band quantification was carried out using ImageJ software [63].

\section{Additional material}

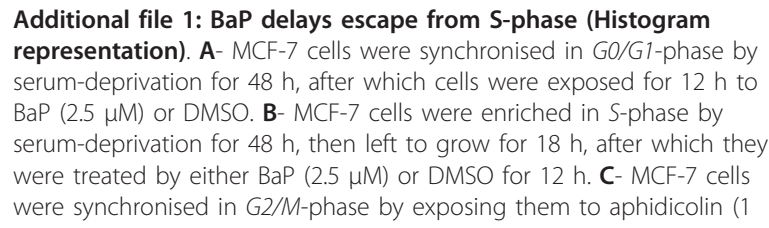


$\mu \mathrm{g} / \mathrm{mL})$ for $24 \mathrm{~h}$ followed by colchicine $(0.25 \mu \mathrm{M})$ for $12 \mathrm{~h}$. Subsequently, they were released into media containing either BaP $(2.5 \mu \mathrm{M})$ or DMSO for $12 \mathrm{~h}$. Cell cycle distribution was examined by flow cytometry and DNA histograms were generated. The profiles are representative of three independent experiments.

Additional file 2: List of differentially-expressed genes common to G1-, S- and G2/M-enriched cultures after $12 \mathrm{~h} \mathrm{BaP}(2.5 \mu \mathrm{M})$ treatment. Only genes which had a change of 1.5 -fold after BaP exposure are shown

Additional file 3: List of differentially-expressed genes common to G1- and S-enriched cultures only after $12 \mathrm{~h} \mathrm{BaP}(2.5 \mu \mathrm{M})$ treatment Only genes which had a change of 1.5 -fold after BaP exposure are shown.

Additional file 4: List of differentially-expressed genes common to G1- and G2/M-enriched cultures only after $12 \mathrm{~h} \mathrm{BaP}(2.5 \mu \mathrm{M})$ treatment. Only genes which had a change of 1.5 -fold after BaP exposure are shown.

Additional file 5: List of differentially-expressed genes common to $S$ - and G2/M-enriched cultures only after $12 \mathrm{~h} \mathrm{BaP}(2.5 \mu \mathrm{M})$ treatment. Only genes which had a change of 1.5 -fold after BaP exposure are shown.

\section{Additional file 6: Ingenuity pathway analysis (IPA) figures legend.}

Additional file 7: List of the top five scoring network in each enriched culture. Scores are obtained within Ingenuity pathway analysis (IPA) software.

Additional file 8: Gene expression primers and probes used in RTPCR reactions. The assays were purchased from Applied Biosystems and each consists of 2 primers (forward and reverse) and a Taqman probe.

\section{Acknowledgements}

We thank Dr. Daniel Brewer for advice and help with the statistical analysis. This work was supported by Hamza Hamouchene's PhD studentship from the Institute of Cancer Research and by Cancer Research UK.

\section{Authors' contributions}

DP conceived the study and supervised its design and coordination. HH, IG and VA participated in design and coordination of the study. HH and IG designed the microarray experiments. $\mathrm{HH}$ carried out all experiments and data analysis with the exception of DNA adduct measurements, which were performed by VA. HH drafted the manuscript and DP, VA and IG participated in its preparation. All authors have read and approved the final manuscript.

Received: 13 March 2011 Accepted: 29 June 2011

Published: 29 June 2011

\section{References}

1. Miller EC: Some current perspectives on chemical carcinogenesis in humans and experimental animals: Presidential Address. Cancer Res 1978, 38(6):1479-1496.

2. Miller EC, Miller JA: Milestones in chemical carcinogenesis. Semin Oncol $1979,6(4): 445-460$

3. Gooderham NJaC PL: Mechanisms of chemical carcinogenesis. 2002, 1.

4. Phillips DH: Fifty years of benzo(a)pyrene. Nature 1983, 303(5917):468-472.

5. Gu YZ, Hogenesch JB, Bradfield CA: The PAS superfamily: sensors of environmental and developmental signals. Annu Rev Pharmacol Toxicol 2000, 40:519-561.

6. Crews ST, Fan CM: Remembrance of things PAS: regulation of development by bHLH-PAS proteins. Curr Opin Genet Dev 1999, 9(5):580-587.

7. Khan QA, Dipple A: Diverse chemical carcinogens fail to induce $G(1)$ arrest in MCF-7 cells. Carcinogenesis 2000, 21(8):1611-1618.

8. Puga A, Ma C, Marlowe JL: The aryl hydrocarbon receptor cross-talks with multiple signal transduction pathways. Biochem Pharmacol 2009, 77(4):713-722.

9. Hockley SL, Arlt VM, Brewer D, Giddings I, Phillips DH: Time- and concentration-dependent changes in gene expression induced by benzo (a)pyrene in two human cell lines, MCF-7 and HepG2. BMC Genomics 2006, 7:260.

10. Hockley SL, Arlt VM, Brewer D, Te Poele R, Workman P, Giddings I, Phillips DH: AHR- and DNA-damage-mediated gene expression responses induced by benzo(a)pyrene in human cell lines. Chem Res Toxicol 2007, 20(12):1797-1810.

11. Jiao H, Allinson SL, Walsh MJ, Hewitt R, Cole KJ, Phillips DH, Martin FL: Growth kinetics in MCF-7 cells modulate benzo[a]pyrene-induced CYP1A1 up-regulation. Mutagenesis 2007, 22(2):111-116.

12. Levine-Fridman A, Chen L, Elferink CJ: Cytochrome P4501A1 promotes G1 phase cell cycle progression by controlling aryl hydrocarbon receptor activity. Mol Pharmacol 2004, 65(2):461-469.

13. Santini RP, Myrand S, Elferink C, Reiners JJ Jr: Regulation of Cyp1a1 induction by dioxin as a function of cell cycle phase. J Pharmacol Exp Ther 2001, 299(2):718-728.

14. Klaus A, Birchmeier W: Wnt signalling and its impact on development and cancer. Nat Rev Cancer 2008, 8(5):387-398.

15. Weiss C, Bohmann D: Deregulated repression of c-Jun provides a potential link to its role in tumorigenesis. Cell Cycle 2004, 3(2):111-113.

16. Thiel $\mathrm{G}$, Cibelli $\mathrm{G}$ : Regulation of life and death by the zinc finger transcription factor Egr-1. J Cell Physiol 2002, 193(3):287-292.

17. Yin X, Dewille JW, Hai T: A potential dichotomous role of ATF3, an adaptive-response gene, in cancer development. Oncogene 2008, 27(15):2118-2127.

18. Strelau J, Schmeer C, Peterziel H, Sackmann T, Herold-Mende C, Steiner H, Weller M, Unsicker K: Expression and putative functions of GDF-15, a member of the TGF-beta superfamily, in human glioma and glioblastoma cell lines. Cancer Lett 2008, 270(1):30-39.

19. Kaspar JW, Niture SK, Jaiswal AK: Nrf2:INrf2 (Keap1) signaling in oxidative stress. Free Radic Biol Med 2009, 47(9):1304-1309.

20. Shtivelman E, Sussman J, Stokoe D: A role for PI 3-kinase and PKB activity in the G2/M phase of the cell cycle. Curr Biol 2002, 12(11):919-924.

21. Matsuoka M, Sudo H, Tsuji K, Sato H, Kurita M, Suzuki H, Nishimoto I, Ogata E: ik3-2, a relative to ik3-1/Cables, is involved in both p53mediated and p53-independent apoptotic pathways. Biochem Biophys Res Commun 2003, 312(2):520-529.

22. Tsang WY, Wang L, Chen Z, Sanchez I, Dynlacht BD: SCAPER, a novel cyclin A-interacting protein that regulates cell cycle progression. J Cell Biol 2007, 178(4):621-633.

23. van Delft JH, van Agen $E$, van Breda SG, Herwijnen $M H$, Staal YC, Kleinjans JC: Discrimination of genotoxic from non-genotoxic carcinogens by gene expression profiling. Carcinogenesis 2004, 25(7):1265-1276.

24. Bartosiewicz M, Penn S, Buckpitt A: Applications of gene arrays in environmental toxicology: fingerprints of gene regulation associated with cadmium chloride, benzo(a)pyrene, and trichloroethylene. Environ Health Perspect 2001, 109(1):71-74.

25. Hamadeh HK, Bushel PR, Jayadev S, Martin K, DiSorbo O, Sieber S, Bennett L, Tennant R, Stoll R, Barrett JC, Blanchard K, Paules RS, Afshari CA: Gene expression analysis reveals chemical-specific profiles. Toxicol Sci 2002, 67(2):219-231.

26. Chen H, Liu J, Merrick BA, Waalkes MP: Genetic events associated with arsenic-induced malignant transformation: applications of CDNA microarray technology. Mol Carcinog 2001, 30(2):79-87.

27. Newton RK, Aardema M, Aubrecht J: The utility of DNA microarrays for characterizing genotoxicity. Environ Health Perspect 2004, 112(4):420-422.

28. Mitchell KA, Elferink CJ: Timing is everything: consequences of transient and sustained AhR activity. Biochem Pharmacol 2009, 77(6):947-956.

29. Chang CY, Puga A: Constitutive activation of the aromatic hydrocarbon receptor. Mol Cell Biol 1998, 18(1):525-535

30. Ikuta T, Kobayashi $Y$, Kawajiri K: Cell density regulates intracellular localization of aryl hydrocarbon receptor. J Biol Chem 2004, 279(18):19209-19216.

31. Jeffy BD, Chen EJ, Gudas JM, Romagnolo DF: Disruption of cell cycle kinetics by benzo[a]pyrene: inverse expression patterns of BRCA-1 and p53 in MCF-7 cells arrested in S and G2. Neoplasia 2000, 2(5):460-470.

32. Kastan MB, Bartek J: Cell-cycle checkpoints and cancer. Nature 2004, 432(7015):316-323

33. Nakanishi M, Shimada M, Niida H: Genetic instability in cancer cells by impaired cell cycle checkpoints. Cancer Sci 2006, 97(10):984-989. 
34. Kastan MB, Onyekwere O, Sidransky D, Vogelstein B, Craig RW: Participation of p53 protein in the cellular response to DNA damage. Cancer Res 1991, 51(23 Pt 1):6304-6311.

35. Massague J: G1 cell-cycle control and cancer. Nature 2004, 432(7015):298-306

36. Khan QA, Dipple A, Anderson LM: Protease inhibitor-induced stabilization of p21(waf1/cip1) and cell-cycle arrest in chemical carcinogen-exposed mammary and lung cells. Mol Carcinog 2002, 33(1):1-8.

37. Jiao S, Liu B, Gao A, Ye M, Jia X, Zhang F, Liu H, Shi X, Huang C: Benzo(a) pyrene-caused increased G1-S transition requires the activation of c-Jun through p53-dependent PI-3K/Akt/ERK pathway in human embryo lung fibroblasts. Toxicol Lett 2008, 178(3):167-175.

38. Ou YH, Chung PH, Hsu FF, Sun TP, Chang WY, Shieh SY: The candidate tumor suppressor BTG3 is a transcriptional target of p53 that inhibits E2F1. EMBO J 2007, 26(17):3968-3980.

39. Long DJ, Waikel RL, Wang XJ, Perlaky L, Roop DR, Jaiswal AK: NAD(P)H: quinone oxidoreductase 1 deficiency increases susceptibility to benzo(a) pyrene-induced mouse skin carcinogenesis. Cancer Res 2000, 60(21):5913-5915.

40. Anwar A, Dehn D, Siegel D, Kepa JK, Tang LJ, Pietenpol JA, Ross D: Interaction of human $\mathrm{NAD}(\mathrm{P}) \mathrm{H}$ :quinone oxidoreductase 1 (NQO1) with the tumor suppressor protein $\mathrm{p} 53$ in cells and cell-free systems. J Biol Chem 2003, 278(12):10368-10373.

41. Nebert DW, Dalton TP, Okey AB, Gonzalez FJ: Role of aryl hydrocarbon receptor-mediated induction of the CYP1 enzymes in environmental toxicity and cancer. J Biol Chem 2004, 279(23):23847-23850.

42. Duriez C, Moyret-Lalle C, Falette N, El-Ghissassi F, Puisieux A: BTG2, its family and its tutor. Bull Cancer 2004, 91(7-8):E242-253.

43. Wade PA: Transcriptional control at regulatory checkpoints by histone deacetylases: molecular connections between cancer and chromatin. Hum Mol Genet 2001, 10(7):693-698.

44. Kim JH, Stansbury KH, Walker NJ, Trush MA, Strickland PT, Sutter TR: Metabolism of benzo[a]pyrene and benzo[a]pyrene-7,8-diol by human cytochrome P450 1B1. Carcinogenesis 1998, 19(10):1847-1853.

45. Williams JA, Martin FL, Muir GH, Hewer A, Grover PL, Phillips DH: Metabolic activation of carcinogens and expression of various cytochromes P450 in human prostate tissue. Carcinogenesis 2000, 21(9):1683-1689.

46. McFadyen MC, Melvin WT, Murray Gl: Cytochrome P450 CYP1B1 activity in renal cell carcinoma. Br J Cancer 2004, 91(5):966-971.

47. Wu MF, Wu WJ, Chang GC, Chen CY, Hu SW, Tsai WT, Lee H, Lin P: Increased expression of cytochrome P4501B1 in peripheral leukocytes from lung cancer patients. Toxicol Lett 2004, 150(2):211-219.

48. Buters JT, Sakai S, Richter T, Pineau T, Alexander DL, Savas U, Doehmer J, Ward JM, Jefcoate CR, Gonzalez FJ: Cytochrome P450 CYP1B1 determines susceptibility to 7, 12-dimethylbenz[a]anthracene-induced lymphomas. Proc Natl Acad Sci USA 1999, 96(5):1977-1982.

49. Keshava C, Whipkey D, Weston A: Transcriptional signatures of environmentally relevant exposures in normal human mammary epithelial cells: benzo[a]pyrene. Cancer Lett 2005, 221(2):201-211.

50. Burczynski ME, Lin HK, Penning TM: Isoform-specific induction of a human aldo-keto reductase by polycyclic aromatic hydrocarbons (PAHs), electrophiles, and oxidative stress: implications for the alternative pathway of PAH activation catalyzed by human dihydrodiol dehydrogenase. Cancer Res 1999, 59(3):607-614.

51. Penning TM, Burczynski ME, Hung CF, McCoull KD, Palackal NT, Tsuruda LS: Dihydrodiol dehydrogenases and polycyclic aromatic hydrocarbon activation: generation of reactive and redox active o-quinones. Chem Res Toxicol 1999, 12(1):1-18.

52. Shimada T: Xenobiotic-metabolizing enzymes involved in activation and detoxification of carcinogenic polycyclic aromatic hydrocarbons. Drug Metab Pharmacokinet 2006, 21(4):257-276.

53. Kyriakis JM, Avruch J: Mammalian mitogen-activated protein kinase signal transduction pathways activated by stress and inflammation. Physiol Rev 2001, 81(2):807-869.

54. Grisendi S, Mecucci C, Falini B, Pandolfi PP: Nucleophosmin and cancer. Nat Rev Cancer 2006, 6(7):493-505.

55. Bartek J, Lukas C, Lukas J: Checking on DNA damage in S phase. Nat Rev Mol Cell Biol 2004, 5(10):792-804.

56. Budanov AV, Karin M: p53 target genes sestrin1 and sestrin2 connect genotoxic stress and mTOR signaling. Cell 2008, 134(3):451-460.
57. Roos WP, Kaina B: DNA damage-induced cell death by apoptosis. Trends Mol Med 2006, 12(9):440-450.

58. Saigusa K, Imoto I, Tanikawa C, Aoyagi M, Ohno K, Nakamura Y, Inazawa J: RGC32, a novel p53-inducible gene, is located on centrosomes during mitosis and results in G2/M arrest. Oncogene 2007, 26(8):1110-1121.

59. [http://www.facslab.toxikologie.uni-mainz.de/engl.\%20Websites/Downloadsengl.jsp].

60. Phillips DH, Arlt VM: The 32P-postlabeling assay for DNA adducts. Nat Protoc 2007, 2(11):2772-2781.

61. Phillips DH, Castegnaro M: Standardization and validation of DNA adduct postlabelling methods: report of interlaboratory trials and production of recommended protocols. Mutagenesis 1999, 14(3):301-315.

62. GEO:[http://www.ncbi.nlm.nih.gov/geo/].

63. ImageJ:[http://rsbweb.nih.gov/ij/].

\section{doi:10.1186/1471-2164-12-333}

Cite this article as: Hamouchene et al:: Influence of cell cycle on responses of MCF-7 cells to benzo[a]pyrene. BMC Genomics 2011 12:333.

\section{Submit your next manuscript to BioMed Central and take full advantage of:}

- Convenient online submission

- Thorough peer review

- No space constraints or color figure charges

- Immediate publication on acceptance

- Inclusion in PubMed, CAS, Scopus and Google Scholar

- Research which is freely available for redistribution

Submit your manuscript at www.biomedcentral.com/submit
C Biomed Central 